\title{
A medical union in the United States
}

\author{
J D J HAVARD
}

Recent developments in the provision of health care in the United States have created serious problems for American doctors. The traditional independent doctor-hospital relationship has changed and doctors have suffered a marked diminution in their individual authority as a result. Membership of the staff of a hospital or health care institution has become a condition of successful practice and the well-organised and powerful health insurance bodies are exercising increasing control over doctors working in hospitals and institutions. The introduction of utilisation review committees for hospitals catering for Medicare patients and the statutory requirement for hospitals to set up professional standards review organisations to monitor the medical care provided to Medicare beneficiaries have led to hospital authorities exercising unprecedented control over their medical staff.

In a recent visit to the USA I found that the doctors themselves, unlike their new masters, are hardly organised at all to defend their professional or financial interests. The AMA and the State medical societies to which they are affiliated have adopted a reactionary attitude to all these changes and have flatly refused to form themselves into a union. Instead, they are trying to meet the problem by setting up courses for individual doctors on collective bargaining, while declining to do the job themselves on behalf of their members on grounds that such activities are inconsistent with the professional activities of the association. A similar attitude adopted by the American Nurses Association has led to increasing numbers of nurses joining the Teamsters' Union (roughly equivalent to the Transport and General Workers' Union).

\section{Legality of collective action}

The Federal and State laws relating to the combination of workers in the form of trade unions are remarkably confused so far as the medical profession is concerned. Despite the increasing control exercised by the hospital and insurance bodies over doctors, they are regarded as self-employed, so that immunity from prosecution for conspiracy or restraint of trade is not technically available to them in respect of action taken against them. Yet hospitals may be liable to malpraxis (negligence) for the acts and omissions of their doctors. This makes no sort of sense so far as the law of master and servant and of agency is concerned. But there are now signs that the law is beginning to accept that doctors are entitled to take collective action in the face of unreasonable impositions by an employer. It is interesting that state prosecutors have been noticeably reluctant to pursue "antitrust" actions against groups of doctors who have combined together against their "employers." The reason for this is twofold. Firstly, it would almost certainly lead, on appeal, to a clarification of the law in favour of doctors; and, secondly, the consequences would be such as to strengthen considerably the membership of the Union of American Physicians and Dentists (UAPD), which was founded in 1972 to do what the AMA and the State medical societies are not prepared to do, which is to represent the profession in the collective bargaining of terms and conditions of service. The

British Medical Association, BMA House, Tavistock Square, London WC1H 9JP

J D J HAVARD, MD, LLB, principal deputy secretary union has already achieved some impressive results in challenging through the courts certain repressive actions of employing authorities.

It is difficult to see why the AMA and State medical societies have felt unable to intervene in some of the more unethical actions of the insurance bodies, in particular the inspection by lay officials of the records of patients participating in Medicaid or Medicare. These inspections take place without the express and informed consent of the patient. The inspectors, who are sometimes retired police officers, may call at the doctor's surgery without notice and demand to see patients' records. The justification advanced for this appears to be that the patient who accepts medical care which includes a governmental financial contribution forfeits, among other things, all rights to privacy. The union is challenging these inspections through the courts, with some success.

\section{Further outlook}

The outlook for the medical profession in the United States, with increasing participation of the State in the provision of health care, is not promising. The profession has had an appalling press, with the media concentrating on the relatively high standard of living of doctors and the immense number of medical negligence cases. (In Britain, however, a large proportion of these cases would never get to the courts as they are the result of the contingency principle whereby the lawyer gets a proportion of the amount recovered as damages by the patient. Such an arrangement is regarded here as unethical and would result in disciplinary action by the Law Society or Bar Council.) The effect of all this on a profession whose sensitivity to public criticism is well known has been demoralisation. Substantial cuts have been made in certain fees, with only a token resistance from the profession, and the fees for many services have nowhere near kept up with inflation. Among the chief sufferers have been those who practise among the poor in the inner city areas.

The prevailing mood in the profession is one of fatalism. Those doctors whose independence and income have not yet been seriously eroded appear to be resigned to their ultimate fate, and show little concern about what is happening to their less fortunate colleagues. In a recent article on physicians' unions Professor Craver ${ }^{1}$ summed up the attitude of the profession to their leaders as follows:

"Although the American Medical Association (AMA) purports to represent the interests of all physicians, many of the activist, organisation-minded physicians believe that it has thus far done relatively little to provide doctors with meaningful assistance concerning their dealings with health care institutions. Furthermore, they are quite sceptical regarding the possibility that the AMA will significantly alter its posture in the future."

Yet it is easy to forget that only very recently a large number of doctors in the UK were reluctant to acknowledge formally the BMA's trade union activities, though these had been successfully conducted for many years under a professional banner. But when the BMA was confronted by the Trade Union and Labour Relations Act of 1974, which required it to register as an ordinary trade union or to withdraw altogether from effective collective bargaining on behalf of the profession, there was never any serious doubt about which decision the members would have to take. Few doctors may have noticed (and no one objected) to the resolution proposed by the BMA Council at the Special Representative Meeting in 1975 that certain changes should be 


\section{In brief}

\section{GMC election 1979}

The closing date for the receipt of nomination papers by the General Medical Council was 3 May and 176 candidates are standing. A list of the 50 BMA-sponsored candidates was published on 28 April, p 1162, and their election addresses will be published on 23 June. The postal election will be held between 4 July and 1 August and the new GMC will take office on 27 September.

\section{MPs' help sought}

The BMA has written to MPs whose constituencies include Service hospitals to draw their attention to the crisis in the medical branches of the armed Forces. Premature voluntary retirement is increasing, recruitment is below target, and the Association hopes that MPs will urge the Government to take action to improve pay and stop any further deterioration of differentials.

Fee for professional competence inquiries

The daily fee for members who sit on inquiries into professional competence (set up under Circular $\mathrm{HM}(61) 112$ ) has been increased to $£ 18 \cdot 40$, backdated to 1 January 1979 . The last increase to $£ 12$ was in November 1974.

Increased milage allowances for study courses

General practitioners and their ancillary staff will be able to claim increased milage allowances for attending courses arranged under Section 63 of the Health Services and Public Health Act 1968. For courses attended on or after 1 December 1978 the new rate is $6.7 \mathrm{p}$ per mile; for courses on or after 1 February 1979 the rate is $7 \cdot 0 \mathrm{p}$ per mile.

\section{Professional unions to see Mr Prior}

Representatives of the Managerial, Professional, and Staff Liaison Group will meet the Secretary of State for Employment, $\mathrm{Mr}$ James Prior, on 13 June to discuss various industrial relations issues which have been raised in correspondence with his Department. The group-which represents half a million managers, professional and other staff employees, including the BMA-has also submitted a document on taxation to the Chancellor of the Exchequer and asked for a meeting.

Before the election the Private Office of the Conservative Party assured the group that the next Conservative Government would "certainly wish to ensure that the views of managers and professional staff are taken fully into account and will consult the MP and SLG on appropriate matters." It would also want "to ensure fair representation for trade unionists, including politically independent trade unions. Unions should be accorded equal treatment whether or not they are affiliated to the TUC."

In a letter sent after her election Mrs Thatcher said that Ministers would take

advantage of the group's offer of consultation "in the normal consultations with trade unions."

\section{HP grade: revised circular}

A draft revised circular on arrangements for appointing hospital practitioners is now being considered by the JCC, CCHMS, GMSC, and the RCGP. The DHSS has incorporated points raised by the profession and the circular no longer provides for an "initial review" of hospital posts held by GPs with a view to their possible regrading as hospital practitioner posts. An annex on the criteria for appointment to the grade has also been excluded as it has been agreed that these should be drawn up by the profession. The appointments are for principals in general practice and are limited to a maximum of five sessions a week. The CCHMS negotiators are negotiating a hospital practitioner grade mark II for doctors not eligible for the mark I grade (19 May, p 1363).

\section{Association Notices}

\section{Amalgamation of Manchester Division and Salford Division}

Notice is hereby given by the Council to all concerned that the Manchester Division and he Salford Division have been amalgamated to form one division, to be known as the Manchester and Salford Division.

\section{E GREY-TURNER Secretary}

\section{Amalgamation of St Marylebone and North-east Westminster Division and Paddington Division}

Notice is hereby given by the Council to all concerned that the St Marylebone and North- east Westminster Division and the Paddington Division have been amalgamated to form one division, to be known as the St Marylebone, North-east Westminster, and Paddington Division.

\section{E GREY-TURNER} Secretary

\section{Amalgamation of Greenwich Division and Bexley Division}

Notice is hereby given by the Council to all concerned that the Greenwich Division and the Bexley Division have been amalgamated to form one division, to be known as the Greenwich and Bexley Division.

E GREY-TURNER Secretary made to the Articles of Association and Bylaws. They were mainly concerned with the final interment of the Chambers Report. One of the changes, however, was the deletion of the proviso to the Article which prohibited the BMA from undertaking activities which would make it a trade union. Previously, it had been necessary to adopt the device of converting the BMA into the British Medical Guild for the purpose of conducting such activities. So in protecting the profession's interest doctors in Britain have adopted a much more practical approach than have their colleagues in the USA.

American doctors have shown great interest in the history of state participation in the provision of health care in the United Kingdom, and in particular the role of the BMA during the past
65 years in ensuring that important rights have been preserved, such as choice of patient by doctor (and doctor by patient), clinical freedom, the right to participate or not to participate in the Health Service, freedom to prescribe, and the right to practise as an independent contractor. All in all, this appears to American doctors as an impressive achievement in light of the fact that the medical profession in England has had a near-monopoly employer for more than 30 years.

\section{Reference}

${ }^{1}$ Craver, C H, The Hastings Law fournal, 1975, 27, 55. 